\title{
COMPARISON OF FARM PRODUCTION AND MARKETING COST AND BENEFIT AMONG SELECTED VEGETABLE POCKETS IN NEPAL
}

Deepak Mani Pokhrel, $\mathrm{PhD}^{1}$

\begin{abstract}
In vein of exploring vegetable production and marketing related problems that could have hindered farmers from getting potential benefit, the study evaluates farm performances in selective vegetable pockets of Kabhrepalanchok, Sindhupalchok and Kaski districts. It describes farm strategies on pre and post harvest crop management, explores marketing channels and mechanisms of commodity transfer and price formation and assesses farm benefits of selective crops. Study method is based on exploration of processes and costs of production and marketing following observations and short interviews with local farmers in small groups, local traders in market centers and local informants. Marketing channels are explored, farm profits and shares on wholesale prices explained through cost-benefit assessments and prospects of vegetable production and marketing described.
\end{abstract}

Key words: Cost-benefit, marketing-channel, Nepal, price-share, production-marketing system, vegetable pockets, mountain

\section{INTRODUCTION}

Nepalese agriculture has been confronting low return depriving farmers of their improvement in livelihood. Especially the mountain people who survive by cultivating cereals on mountain slopes, river basins and small valleys to meet their basic needs, due to poor income, frequently suffer from food-deficiency with low affordability for it. As a solution to which, and thereby to reduce farm-poverty, the country, through various plans and policies (NPC, 1995; NPC, 1998; NPC, 2003; NPC, 2007; MOAC, 2004; MOICS, 1992), identified 'vegetable' as one of the leading sub-sectors to harness advantages of agroecological diversities and has undertaken vegetable promotion strategy especially in the small holders visualizing comparative advantages of vegetable production and marketing in economic growth and development and thereby poverty reduction. Over the time and commensurate with the national vision, many state agencies including those supported by donors are, in their various capacities, engaged in vegetable production and marketing promotion in the country. However, the goal is not achievable unless a fairly operating marketing system and a market oriented production system are instituted. Because, before venturing on such enterprises, farmers first consider the accruable profit(s) that largely depends on the prices or market operations and conversely market oriented improvements in production mechanism that helps farmers in fetching higher prices.

\section{PROBLEM STATEMENT}

It has been a general mention that the farmers, especially vegetable growers, are fetching reasonable price. However, on the ground of higher visible prices in retail markets and without considering farm investments on production processes and intermediaries' costs on commodity transfer at various levels, the farmers claim that they are not sharing fairly on the consumers' prices. The prices available to the farmers could be genuine, when considered low storability, fresh consumption-pattern and high-volume and sophisticated transportation need of vegetable produces that render vegetable marketing a complex business incurring higher costs and risks at traders' level as well (Pokhrel, 2005).

\footnotetext{
${ }^{1}$ Senior Horticulture Development Officer (MOAC), deepakmpokhrel@yahoo.com.
} 
Elsewhere, studies on agriculture marketing systems revealed several problems to influence farm income and production and marketing decision reached by farmers, which were broadly associated with fragmented and imperfect marketing situations and policy matters. Imperfect marketing refers to non-competitive situation of price formation. Many socioeconomic conditions in part of farmers and overall marketing structure contribute to creating such situation. For example, farmers are generally poor, less educated and socially powerless. Such situations of farmers coupled with seasonal shortfall of cash, nonstorability of vegetables at farm condition and poor availability of price information render them weak in market competition. Based on such reasoning and visualizing limited number of middlemen paying low to farm produces, some literatures have mentioned that intermediaries were exploiting farmers (Pradhan, 1998; Shrestha and Shrestha, 2000). Regarding agriculture marketing in Nepal, a general remark had been such that the traders usually tried transferring all sort of price risks to farmers and offered low prices to them by creating monopsonistic situation, debt-ties and cartel (Thapa et al., 1995). However, such things are not studied in view of vegetable production and marketing in Nepal. The traders might have been doing good jobs; they should not be observed as exploiting farmers just by comparing farmers and consumers' prices, and merely based on study of a component in the system. Many components of a marketing system like production and intermediation are equally responsible for a reduction in farm income. Therefore, studying farm performance of vegetable production and marketing from system perspective is very important to know how different components in the system affected it.

Therefore, different aspects of market oriented production and market operation for vegetable crops need to be identified precisely to improve smallholder farm economy. Unless the associated problems are identified and abated, alleviating poverty in the farming communities as envisaged by national development goal would not be possible. Real problems in the system can only be described, when the economy of production mechanism and marketing system for major vegetable products operating in a particular area is evaluated.

On such ground, an evaluation of vegetable production and marketing was carried out in selected pockets in Kabhrepalanchok and Sindhupalchok districts along Arniko Highway and Hemja of Kaski district to analyze vegetable production and marketing system with major focus on cost-benefit and mechanisms of commodity production and transfer, where farmers are, with a fetch of good income from vegetable production, reported improving socio-economic condition in the recent years (DADO, 2006: DADO, 2007a and DADO, 2007b). The farmers in the localities have been growing many vegetables commercially. The details such as how the farmers are successful in commercial vegetable production and how are they disposing the produces and fetching prices are little known to the societies beyond the farming community.

\section{RATIONALE OF THE STUDY}

Vegetable production and marketing is gradually emerging as an important sub-sector contributing to gross domestic product (GDP) in Nepal. Agriculture sector contributed about 33 percent to the GDP (MOAC, 2007a) with 14.38 percent (about two-third of total horticultural share) shared by vegetables including potato (MOAC, 2007b). According to an estimate, area under vegetable crops in the recent years is increasing by nearly five percent per annum. In addition, the productivity and accordingly the production show an increasing trend (MOAC, 2007a). Apart from which, vegetable is a potential source of export earnings, rural employment and economic growth (NPC, 1995). In such situations, improving production and marketing efficiencies is only way to sustain local produce in the market. However, the country is not able to harness available market for vegetables, and different factors at production and marketing levels hindering vegetable business are not fully identified and abated. 
Studies on vegetable production and marketing to substantiate economic relation between farmers and traders are limited in Nepal. Some rapid market appraisals and national seminars have raised some issues as problems. They observed farmers' poor access to fair prices and marketing support services and policy weakness as major problems (Koirala et al., 1995; Thapa et al., 1995; Partap, 1999; Banskota and Sharma, 1999; Banskota, 1999; AEC/FNCCl/ WI/MOA, 1996; FAO, 1998; MOA, 1998; Chapagain and Phuyal, 2003). However, such articles and seminar papers describing national perspectives of agriculture marketing are not adequately based on empirical information due to lack of micro level studies. Review of the literatures also suggests that farmers' problems are generally ignored during policy formulation due to lack of farm level information. This study addresses such gaps and empirical evidences from such studies help in proper policy formulation and program planning regarding vegetable production and marketing promotion.

\section{CONCEPTUAL FRAMEWORK}

Production, in any agribusiness, is a process of creating a commodity (mainly primary product), which is subject to marketing. Marketing, in general, refers to the process of price-decision for a good by seller and buyer together, and market to the place where such decision takes place (Ellis, 1996). Marketing as a process involves many operations in price formation of a commodity such as transfer, value addition and intermediation. A market can be nearly perfect to imperfect depending on buyers and sellers' influence on price formation, and integrated or fragmented depending on availability of transport and communication among the market participants (Hanson, 1982). Marketing system refers to the channel along which commodity passes through a sequence of stages or events, and it varies with commodity and other factors such as distance, infrastructure and producer's awareness (Ellis, 1996). Price signal transmission and physical transmission of the commodities are major functions of marketing; carrying out such by a market depends on number and size of participants, information system and the physical infrastructure. The physical transmission function can further be differentiated in terms of time, space and form dimensions.

For an analysis of an agricultural production-marketing system, different approaches such as structure-conduct-performance, marketing system, institutional, functional, demand projection, marketing mix, value chain and sub sector analysis have been discussed in literatures. Though termed differently, the approaches, to assess efficiency of commodity and information flow along marketing channel, describe market structure, its quality of operation and factors to influence its operation. Literatures on system-based analysis of agricultural production and marketing, especially at micro level, are very rare. Mechanism of production and marketing varies with commodity and locations including other factors as well (Pokhrel, 2005).

Farms, through investment of scarce resources on various inputs and production processes, produce crops of their choice and supply the produces to market. Such actions by farmers for a commodity depend on price signal (demand chain) and physical transmission (supply chain) functions of marketing systems (Ellis, 1996). In a production integrated marketing, such a process of two way transfer is efficient rendering the production system demandresponsive as determined by a number of factors, broadly associated with infrastructure, socioeconomic attributes, policies and institutions (Pokhrel, 2005). Influenced by such factors, the system's operation consequently affects the production and marketing decisions reached by market participants including farmers. Most important, it determines economic benefit (margin) accrued to farmers as an incentive for cultivation of a crop. A fair and high price available to farmer has positive impact on farm production decision, which leads to an expansion of the production program and its improvement at farm level. In contrast, an unfair and low price available to farmer affects farm production decision negatively, and renders him/her reluctant in continuing the production program (Pokhrel, 2005). Therefore, 
evaluating farm level production expenses and relative profits and prices is very important. A detail analysis of such things involves evaluation of marketing channel and the functions carried out by different components in the production-marketing system. A wider coverage of value-chain and/or marketing components such as intermediation, distribution, storage, processing, consumption and marketing support services, though would be much relevant, was not possible due to time and resource limitations.

\section{MATERIALS AND METHODS}

The study was carried out as an exploratory and cross-sectional type seeking answers to 'what' occurs, and 'how' the process operates in a particular segment of society. In such pursuance, the study explored vegetable-based production processes, major cropping patterns followed and marketing channels including structural elements such as types of participants, their roles and behavioral interaction among them. Major stakeholders in the vegetable production and marketing system(s) including mainly the farmers (in small groups of 5-7), the traders and the business associations such as cooperatives and market centers were selected using snowball method and purposive technique of sampling and consulted through focus group discussions and informal interviews during March and April of 2008 (Annex 1). Participatory cost-benefit analyses on production and marketing of major vegetable crops were applied to explain farm profits and shares on wholesale prices. Secondary information on vegetable collection and prices was also collected from District Agriculture Development Offices (DADOs) and market centers where available. Structured checklists were used while interviewing farmers in groups and observing production sites and market centers. The quantitative data thus collected were input and analyzed in spreadsheet of Microsoft Excel such as cost-benefit, and the qualitative data through descriptive approaches such as marketing channel and Strength, Weakness, Opportunity and Threats SWOT analyses.

\section{RESULT AND DISCUSSION}

\section{FARM STRATEGY IN COMMODITY PRODUCTION}

Scale and quality of production, productivity and pre-marketing farm level management of marketable products are important issues of supply management, which affect price of the products and overall efficiency of the production and marketing system.

All the vegetable pockets considered in this study are situated in mountain slopes or valley land with subtropical to temperate type of climate. Majority of vegetable growing households had below 10 ropani1 size of holding. Hemja Village Development Committee (VDC) of Kaski district is adjoining to Pokhara Sub-Municipality $(8-13 \mathrm{~km})$, a tourist center, linked by Pokhara-Baglung road to national transportation network. Having irrigation facility in major area of the VDC, paddy in summer is generally followed by two or three crops of vegetable in succession. The farmers preferred growing especially potato (75 percent farmers cultivated potato in more than 50 percent area), cauliflower, cabbage, tomato and cucumber in order. Tomato followed by two months' fallowing or pole bean in plastic houses2 and, in open field, paddy followed by potato or cauliflower or cabbage then radish or cauliflower or cabbage (relayed) and then followed by cucumber mixed in maize has been major annual pattern of crops. Conscious of consumers' preference, Hemja farmers preferred potato production especially MS-42.3 that produced higher yield and fetched better prices even though the variety is not formally recommended on account of its susceptibility to wart disease. Excluding about 1500 farm households cultivating potato,

\footnotetext{
${ }^{1}$ Unit of land in the study area 19.66 ropani of land is approximately 1 ha.

2 There were about 500 plastic houses (2-5/farmer), in major $20 * 6.5 \mathrm{~m}^{2}$ in size that varied from $10 * 5$ to $20 * 15 \mathrm{~m}^{2}$ in size.
} 
more than 115 farmers were reported in Hemja producing vegetables (DADO, 2007b). The farmers used high yielding varieties like MS-42.3 and Janakdev in potato, Bhaktapure in cucumber and imported hybrid varieties in cabbage, cauliflower and tomato. Because of being near to service center in Hemja and DADO and other service providers in Kaski, the farmers had better access to technology. Seventy-five percent of the households growing potato used, on an average, 20 bags of poultry manure in a ropani of land to fertilize the land. Following which, in case of vegetables and other crops, they used a little farmyard manure (FYM), some fertilizers and limited pesticides. Micronutrients such as borax and molybdenum were used exclusively on cabbage and cauliflower in open field and tomato in plastic houses. However, compared to vegetable pockets in Kabhrepalanchowk, the farmers were observed to use less quantity of fertilizers, micronutrients and pesticide in vegetables, and compared to other crops higher quantity of organic manures on potato and tomato being conscious of heavy use of pesticides suppressing natural predators and thereby increasing insect-pest infestations. A plastic house of $20 * 6.5 \mathrm{~m} 2$ size produced a net farm income of 26-50 thousand rupees annually depending on cultivation practices, varieties and market situation. Planting tomato in the plastic house started right from June and harvesting, started from the end of July ended by April. Because of long crop period, farmers generally used heavy basal dose of FYM and frequent application of fertilizers including micronutrients. Furthermore, the farmers planned tomato plantation in plastic houses to produce major harvests by July, when the supply in market is low and prices are high.

Majority of vegetable pockets in Kabhrepalanchowk and Sindhupalchowk are near to capital city Kathmandu and/or border market in Tibet linked by Arniko Highway. Vegetable farmers in Kabhrepalanchowk mainly produced tomato (in open field) followed by cauliflower, cucumber and long-bean in quantity. A similar trend of crop selection was observed in Sindhupalchowk, where farmers, on scale of production basis, ranked cauliflower, tomato, cabbage, bittergourd, long-bean, hot-chili and polebean in order. The farmers fetched higher average prices for the crops as compared to others ranking behind (Table 1). The farmers in Kabhrepalanchowk generally cultivated 3-5 ropani of land under vegetablecrops, and they had almost year-round supply of tomato, cauliflower,

cabbage and radish and a long duration supply of long-bean,

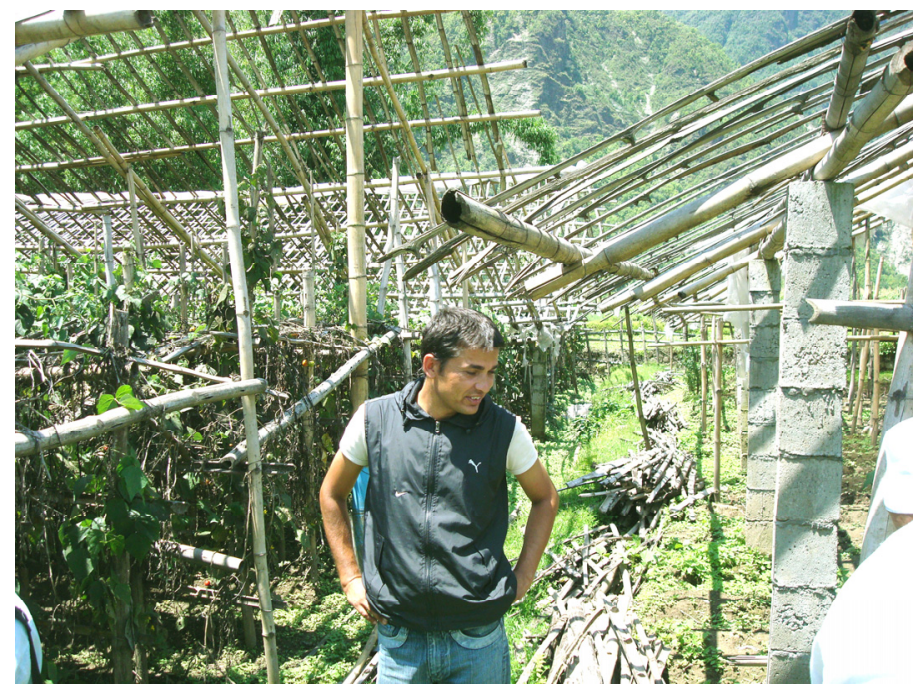

Fig. 1: Plastic houses under preparation for new season crop hot-chili and cucumber during summer. Contrasting to Hemja pocket in Kaski, vegetable growers in the area used farmyard manure and higher dose of chemical fertilizers to fertilize vegetable plots and higher dose and more frequent application of pesticides in crop protection. According to local informants, the farmers disposed most of the vegetable products in the 
local markets along the highway. Nearly $75 \%$ of the disposal was, in different way, transported to Kathmandu. Banepa-market, supposed to receive only 35\% production from its command area in Kabhrepalanchowk as well as Sindhupalchok annually collected nearly 3,400 tons of vegetables. More than fifty locations along the highway and its link-roads were reported collecting vegetables from hinter areas.

Table 1: Annual collection of fresh-vegetables at Kabhreli tarkari bazaar, Banepa

\begin{tabular}{|c|c|c|}
\hline Commodity & Collection $(\mathrm{t})$ & Average price/kg \\
\hline Tomato & 1176 & 21.9 \\
\hline Cauliflower & 624 & 19.6 \\
\hline Cucumber & 450 & 12.8 \\
\hline Long bean & 200 & 20.1 \\
\hline Hot-chili & 190 & 22.5 \\
\hline Radish & 171 & 6.9 \\
\hline Cabbage & 148 & 8.5 \\
\hline Bitter gourd & 146 & 16.4 \\
\hline Dry onion & 110 & 13.5 \\
\hline Butter bean & 59 & 18.1 \\
\hline Brinjal & 58 & 13.4 \\
\hline Sweet pepper & 30 & 20.2 \\
\hline Bottle-gourd & 24 & 10.1 \\
\hline Total & 3386 & \\
\hline
\end{tabular}

Regarding marketing of farm produces, it is not usual that farmers can sustain price bargain with traders at market centers. Moreover, they are likely to loose bargaining power further if they transport the produces in market centers before price negotiation. Transporting farm produces to the market centers also added costs to the farmers. Therefore, wherever possible, farmers in general were observed to take a strategy of disposing farm products at farm gate (if not road head near to farm) to the collectors in contact, and reducing the scale of crop production (such as cucumber, cabbage and radish) that required farmers to carry up to market centers.

\section{FARMER TO TRADER TRANSFER OF FARM PRODUCTS}

The attitude, behavior and decisions by farmers and traders in their transaction through price fixation affect others' activities, and the system's operation. In such view, local system was evaluated to understand how the farmers and traders negotiated prices for farm produces. Fig. 2 presents a generalized view of vegetable transfer situations from Hemja (Kaski) and Fig. 3 from Kabhrepalanchowk and Sindhupalchok based on farmer and traders' mentions, though constructing a marketing channel required complete follow up and verification of various transactions at every point.

Excluding potato that farmers in Hemja had to store in local condition for sometime to wait for collectors, marketing of vegetable products to collectors took place at farm gate right after harvesting. The farmers had, especially in cases of cabbage and cucumber when collectors were not available, to carry the produces to retail market in Chipledhunga or wholesale market in Shantibanbatika. Based on farm mentions, they disposed $80 \%$ of their produces at farm gate and $10 \%$ in each of the market centers (Fig.2).

Twenty-one percent of total saleable produces in the farms is sold to local small-scale collectors called doke. Packing the vegetables in doko1, they transported it to Pokhara and sold to consumers in footpath and roadside markets. The traders in wholesale and retail markets had a general remark that the doke's practice (buying at farm gate and selling along roadside and footpath) had been detrimental to their business at the market centers.

Excluding a few of those from local villages, majority of the collectors purchasing vegetables in Kaski were from Dhading. They collected $59 \%$ of the farm supplies and transferred $49 \%$ to the wholesale market near Bus Park in Pokhara and the rest $10 \%$ to Shree

\footnotetext{
${ }^{1} \mathrm{~A}$ kind of bamboo basket to carry goods on back
} 
Complex retail market at the city heart. As reported by the wholesale traders in the wholesale market, the area on daily basis supplied nearly 4-5 tons of fresh vegetables to the market that made up 7-10 percentage of total transaction there. However, the supplies from Hemja, as per the traders' remarks, had not been as regular as outside supplies. No visible ducts to storage, export-market and vegetable processing were observed there. Potato, though could be stored in cold storages like elsewhere in Nepal, was not reported there for that the farmers in general stored for sometime in local condition until the collectors purchased and retailed to consumers.

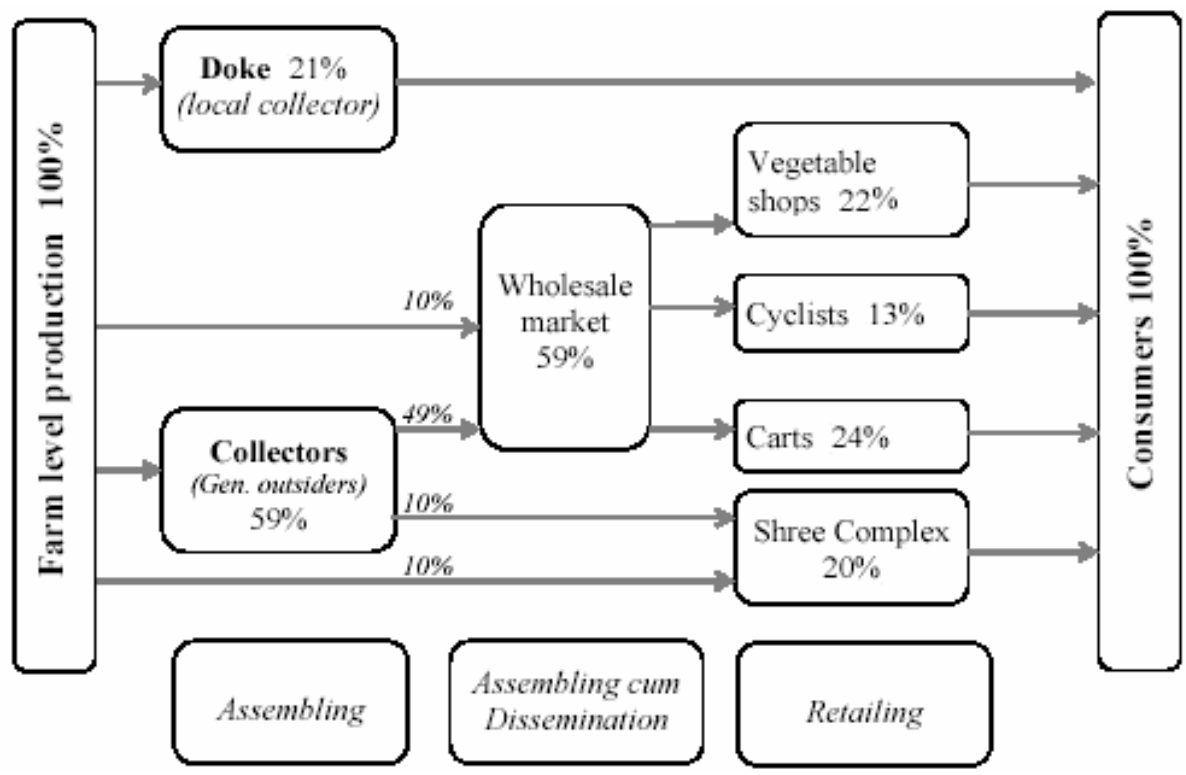

Fig. 2: Vegetable-marketing channels in Hemja (Kaski)

Negotiation system of price formation was observed predominantly to fix on commodity prices as well as, where applicable, commissions between farmer and traders at farm gate as well as wholesale and retail markets. In the system, both farmers and traders bargained for prices and the traders paid the farmers after reaching common agreement. In the commission system that took place only for $10 \%$ of transactions, the traders reimbursed the farmers only after complete disposal of the collection with $10 \%$ deduction from the sale amount as commission. In both the systems, the traders had a general tradition of delaying payment to farmers upon reasoning cash deficit in hand. As a result, some of the farmers had to approach the traders several times to get payment. The farmers were subject to traders' delay in payment while disposing farm produces in retail and wholesale market centers. Contrasting to which, the farmers on sale to vegetable collectors generally received the amount during transactions (Pokhrel, 2005).

The prices fluctuated much and varied depending on demand and supply situations. As per the farms as well as the traders' mentions, farm gate prices in general differed from the wholesale prices by 2-5 rupees per kilogram depending on such situations and the commodity. The traders had generally better knowledge of price and demand situations in the market. The farmers also tried to know the situations from different means such as even asking to different persons in the market. 


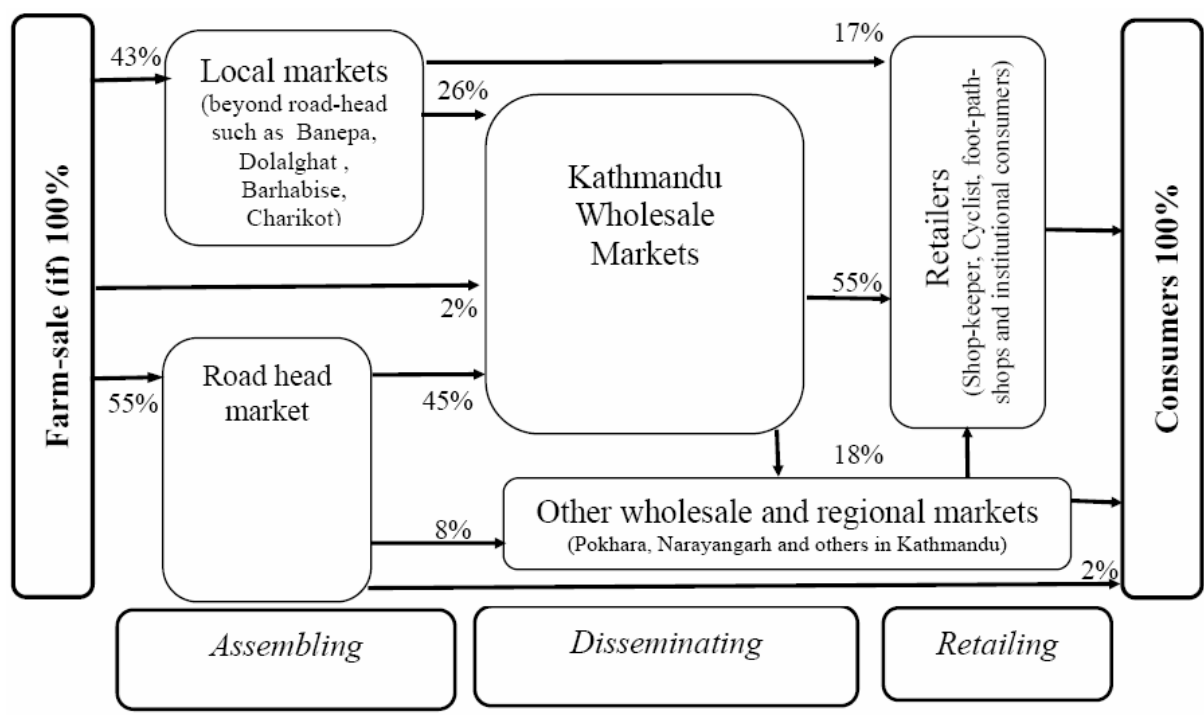

Fig. 3: Vegetable-marketing channels in Kabhrepalanchok and Sindhupalchok

Most of the farmers in Kabhrepalanchowk and Sindhupalchok disposed vegetable products at nearest road-head point ${ }^{1}$ to the traders, either the wholesalers coming from wholesale markets in Kathmandu (Kalimati, Baneshwor and Tukucha) or road-head collectors (mainly shopkeepers) or the farmer-collectors from local villages (Fig.3). The wholesalers or the farmer-collectors later transported the products to Kathmandu or other regional markets such as Charikot, Barhabise, Pokhara and Narayangarh or highway local markets such as Banepa and Dolalghat. The wholesalers generally gathered in the road-head markets for vegetable collection. A limited number of farmer-collectors collecting vegetables from neighborhood disposed vegetables in Banepa or via wholesalers in Kathmandu wholesale markets on commission basis. Apart from the small quantity consumed at local market or transferred to other regional market centers, major part of the road-head collection is canalized to Kathmandu.

When the farmers had to dispose in distant market centers, they packed tomato in crates and other vegetables in poly-bags. Majority of them carried the vegetables contained in dokos or gunny bags to road-head where the traders purchasing them weighed and transferred into crates (if tomato) or poly-bags that in general contained 25 kilogram each. After road-head, the vegetables are transported in mini-trucks. Because of perishable nature of the vegetables and lack of safe storage, the farmers, without any say, have to accept the prices offered by the traders. The traders generally offered a price to the farmers based on wholesale prices in Kathmandu, supply situation of the products both in local and wholesale markets and buyers' concentration in the local markets.

\section{FARM COST-BENEFIT OF VEGETABLE PRODUCTION AND MARKETING}

Farm production and marketing costs for major vegetables as ranked by farmers were examined by farmers' participatory technique to understand the production system's

\footnotetext{
1 such as Banepa, Dhulikhel, Khawa, Kerabari, Tinpiple, Tamaghat, Jirokilo, 54-kilo, Anekot, Mahadevsthan, Baluwa, Shrirampati and Dolalghat in Kabhre and Dolalghat, Chautara, Khandichour, Lamasangu and Barhabise in Sindhupalchowk
} 
performance. The farmers in groups were asked to estimate the costs depending on their practices and experiences, and their net profits based on the prices they generally received. Being aware of farm profitability from a crop that varied with farm-practices, time and location of production and marketing and supply and demand situation in market, only location and time specific assessments of a crop from different groups were averaged. Based on such assessment, the Hemja farmers fetched per ropani annual net income of around 17 thousand rupees from a sequential open field cultivation of cauliflower and cucumber (mixed in maize), and of around 117 thousand rupees from single cropping of tomato in plastic houses. On receiving such profit, the farmers had a total recurring cost of around 10 thousand and 40 thousand rupees respectively (Table 2 ). Contrasting to which,

Table 2: Farm production and marketing cost and benefit in Hemja (Rs. per ropani)

\begin{tabular}{|c|c|c|c|c|c|}
\hline Particulars & Potato & Cauliflower & Cabbage & Tomato & Cucumber \\
\hline \multicolumn{6}{|l|}{ Production materials } \\
\hline Poultry manure/FYM & 5000.00 & 1224.50 & 750.00 & 4924.24 & \\
\hline Fertilizers and micronutrients & 196.60 & 375.00 & 375.00 & 651.52 & 46.00 \\
\hline Seeds & 1250.00 & 150.00 & 110.00 & 757.58 & 200.00 \\
\hline Pesticides and vitamins & 209.00 & 120.00 & 600.00 & 3060.61 & 155.00 \\
\hline Equipment/ other materials & 210.00 & 210.00 & 200.00 & 1363.64 & 200.00 \\
\hline Plastic house: Polythene & & & & 9598.79 & \\
\hline Plastic house: bamboo & & & & 4393.94 & \\
\hline Plastic house: Rope \& others & & & & 663.03 & \\
\hline \multicolumn{6}{|l|}{ Labors } \\
\hline Bullock/ploughman & 800.00 & 600.00 & 600.00 & & 150.00 \\
\hline \multirow{2}{*}{$\begin{array}{l}\text { Workers including family labour } \\
\text { Plastic house construction: } 20 \mathrm{~m} \\
\text { X } 6.5 \mathrm{~m}\end{array}$} & 2100.00 & 2423.00 & 2423.00 & 8181.82 & 4121.00 \\
\hline & & & & 6818.18 & \\
\hline \multicolumn{6}{|l|}{ Marketing } \\
\hline Transport by Worker & & & & & 750.00 \\
\hline Total Expenses & 9765.60 & 5102.50 & 5058.00 & 40413.33 & 4872.00 \\
\hline \multirow{2}{*}{$\begin{array}{l}\text { Net profit } \\
\text { Cost of production and } \\
\text { marketing }(\mathrm{Rs} / \mathrm{kg})\end{array}$} & 7584.40 & 9597.50 & 3442.00 & 117162.43 & 7828.00 \\
\hline & 6.98 & 5.38 & 2.74 & 4.59 & 6.17 \\
\hline
\end{tabular}

the farmers in Araniko road corridor, though the profits varied with locations and farmpractices, were assessed to fetch per ropani net income of 30 thousand rupees from the vegetables with a total investment of about 25 thousand rupees (Table 3 and 4). In a similar study in vegetable pocket of Dhading, Pokhrel and Thapa (2007) observed vegetable farming and farm profit dependant mainly on location specific factors and alternative cultivation options to the farmers, where per ropani annual farm level net profit of vegetable based cropping system ranged from Rs. 161 to 17,860 (as of 2003 prices). While similar assessment by Singh (2008) showed per ropani net profit ranges from Rs 1,760 to 2,518 with an average investment of Rs. 683 to 1008 respectively in Madhyapradesh of India1. The comparison showed higher economic efficiency of vegetable production in Hemja to fetch attractive income. Hemja farmers were also fetching higher prices (Table 5 and 62) due to a deficit supply in market compared to local demands, nearness to market and freshness of local supply. On such ground, Nepalese farmers in highway corridor with a high rate of investment are fetching attractive income from vegetable production. On an average, a farmer in the groups generally cultivated 3-5 ropani land under vegetable-crops contrasting to that of 28 ropani in India as reported by Singh (2008).

\footnotetext{
${ }^{1}$ Converted to Nepalese currency (Rs.100 in Indian currency= Rs.160 in Nepalese currency)

${ }^{2}$ Table 5 compares farm gate prices while Table 6 the road-head price to wholesale price.
} 
Table 3: Farm expenditures and profit on vegetable production and marketing, Kabhre (Rs./ropani)

\begin{tabular}{lcccccc}
\hline \multicolumn{1}{c}{ Particulars } & Tomato & $\begin{array}{c}\text { Long } \\
\text { bean }\end{array}$ & $\begin{array}{c}\text { Cauli- } \\
\text { flower }\end{array}$ & $\begin{array}{c}\text { Bitter- } \\
\text { gourd }\end{array}$ & $\begin{array}{c}\text { Cucum- } \\
\text { ber }\end{array}$ & $\begin{array}{c}\text { Hot } \\
\text { chili }\end{array}$ \\
\hline Production materials & 253 & 253 & 230 & 275 & 253 & 210 \\
Compost/FYM & 460 & 883 & 405 & 1075 & 460 & 450 \\
Fertilizers & 201 & 570 & 600 & 350 & 97 & 350 \\
Seeds & 1510 & 1360 & 350 & 1670 & 1140 & 1000 \\
$\begin{array}{l}\text { Pesticides and vitamins } \\
\text { Plastic sheet/bags }\end{array}$ & 100 & 33 & & 150 & 150 & 100 \\
Staking poles/wood & 2050 & 2033 & & 2675 & 800 & \\
$\begin{array}{l}\text { Equipment/ other materials } \\
\text { Labors }\end{array}$ & 175 & 100 & 278 & 100 & 100 & 100 \\
$\begin{array}{l}\text { Bullock/ploughman } \\
\text { Workers including family labour }\end{array}$ & 225 & 225 & 225 & 225 & 188 & \\
$\begin{array}{l}\text { Marketing } \\
\text { Packaging/ plastic bags }\end{array}$ & 4703 & 3775 & 2525 & 4038 & 4080 & 4500 \\
$\begin{array}{l}\text { Transport by Worker } \\
\text { Transport by vehicle }\end{array}$ & 1167 & 125 & 220 & 300 & 233 & 350 \\
$\begin{array}{l}\text { Fare for the farmer } \\
\text { Load/unload/carry }\end{array}$ & 900 & 1100 & 1600 & 1700 & 100 \\
\hline $\begin{array}{l}\text { Total cost } \\
\text { Net profit }\end{array}$ & & & & & \\
$\begin{array}{l}\text { Production and marketing cost } \\
\text { (Rs/kg) }\end{array}$ & 11068 & 10258 & 5933 & 12458 & 9201 & 7160 \\
\hline
\end{tabular}

Vegetable collections from the pockets were directly disseminated to fresh consumption without any intermediary market. Therefore, the marketing channels are very short with limited participants to share on final commodity prices. Beyond production, the farmers in Kabhrepalanchowk and Sindhupalchok bore transportation cost due to wage labors for delivery of produces at road-head market that ranged from Rs 0.80 to 1.20 per kilogram of produce. In addition to which, the farmers had to spend Rs. $1.20 / \mathrm{kg}$, if they had to transport the produce beyond nearest road-head point. The wholesalers, for transporting vegetables from road-head, on an average spent Rs 2.25 per $\mathrm{kg}$ for packaging material (plastic or crate), transportation and load/unload. Because of time and resource limitations, following a lot of local supply up to wholesale market to observe its real wholesale price was not possible. In view of analyzing farm share on wholesale price, average morning wholesale prices of selective commodities at Kalimati Wholesale Market (Kathmandu) was compared to the road-head market prices of the same commodities at Kabhreli tarkari bazar (Banepa). Such a comparison was made on the price data available for Shrawan of 2063 from both the market centers. The analysis showed that the farmers up on the delivery of vegetable products at road-head, on an average, received about $80 \%(77-88 \%$ in range depending on crops) of the Kalimati wholesale price (Table 5). Conversely, the wholesalers including the farmer-collectors (if any) worked with an average margin of $20 \%$. In addition to which, it was observed in the vegetable marketing system that while weighing each 25 kilogram of vegetable in crate or poly-bag during collection the traders had a discount of almost three kilogram in payment (kachho) as a margin for the containers' weight. In reality and according to the traders, such a margin on the so-called containers helped the traders make up major part of their expenses due to physical damage, weight loss, packing material (poly-bags), load/unload, truck-fare and default payment by retailers. In the context of Madhya Pradesh in India, Singh (2008) observed price-shares by the vegetablegrowers as ranging from 59 (colocasia) to $86 \%$ (onion). On such ground, price-share by the vegetable farmers and general operation by existing vegetable marketing system in the study area look relatively fair. 
Table 4: Farm expenditures and profit on vegetable production and marketing, Sindhu (Rs./ropani)

\begin{tabular}{lcccccc}
\hline \multicolumn{1}{c}{ Particulars } & Tomato & $\begin{array}{c}\text { Long } \\
\text { bean }\end{array}$ & $\begin{array}{c}\text { Cauli- } \\
\text { flower }\end{array}$ & $\begin{array}{c}\text { Bitter- } \\
\text { gourd }\end{array}$ & $\begin{array}{c}\text { Cucum- } \\
\text { ber }\end{array}$ & Hot chili \\
\hline Production materials & 1300 & 1025 & 877 & 542 & 1050 & 600 \\
Compost/FYM & 750 & 535 & 710 & 738 & 300 & 450 \\
Fertilizers & 425 & 297 & 296 & 285 & 90 & 375 \\
Seeds & 775 & 667 & 472 & 600 & 1000 & 300 \\
Pesticides and vitamins & 115 & 0 & 106 & 50 & 100 & 100 \\
$\begin{array}{l}\text { Plastic sheet/bags } \\
\text { Staking poles/wood }\end{array}$ & 1250 & 147 & 0 & 200 & 200 & \\
Equipment/ other materials & 100 & 167 & 100 & 100 & 100 & 100 \\
Labors & & & & & & \\
Bullock/ploughman & 200 & 0 & 200 & 0 & & 400 \\
Workers including family labour & 5800 & 2400 & 2846 & 2700 & 3000 & 5600 \\
Marketing & & & & & & \\
Packaging/ plastic bags & 335 & 100 & 166 & 100 & & 170 \\
Transport by Worker & 300 & 750 & 412 & 800 & 1600 & 100 \\
$\begin{array}{l}\text { Transport by vehicle } \\
\text { Fare for the farmer }\end{array}$ & 600 & 800 & 460 & & & 200 \\
Load/unload/carry & 250 & & 125 & & & 250 \\
\hline Total cost & 400 & & 310 & & & 200 \\
Net profit & 11350 & 6087 & 6185 & 6114 & 7440 & 8195 \\
Cost of production and & 11150 & 6180 & 4759 & 7886 & 5360 & 4305 \\
marketing (Rs/kg) & 7.57 & 7.94 & 8.59 & 7.64 & 4.65 & 16.39 \\
\hline
\end{tabular}

Table 5: Share of farmers in Kabhrepalanchok and Sindhupalchok on Kalimati wholesale prices

\begin{tabular}{|c|c|c|c|c|c|c|}
\hline Price description & Tomato & $\begin{array}{l}\text { Long } \\
\text { bean }\end{array}$ & $\begin{array}{l}\text { Cauli- } \\
\text { flower }\end{array}$ & $\begin{array}{l}\text { Bitter- } \\
\text { gourd }\end{array}$ & $\begin{array}{l}\text { Cucum- } \\
\text { ber }\end{array}$ & $\begin{array}{l}\text { Hot- } \\
\text { chili }\end{array}$ \\
\hline \multicolumn{7}{|l|}{ Farm sale price (Kabhrepalanchok) } \\
\hline Minimum (Rs./kg) & 8.50 & 14.67 & 7.50 & 6.00 & 6.67 & 12.00 \\
\hline Maximum (Rs./kg) & 36.00 & 35.00 & 37.50 & 27.50 & 19.00 & 27.00 \\
\hline Average (Rs./kg) & 18.00 & 20.67 & 20.00 & 16.50 & 11.00 & 14.00 \\
\hline \multicolumn{7}{|l|}{ Farm sale price (Sindhupalchok) } \\
\hline Minimum (Rs./kg) & 6.00 & 11.67 & 7.70 & 11.50 & 3.00 & 15.00 \\
\hline Maximum (Rs./kg) & 37.50 & 23.33 & 27.00 & 25.00 & 15.00 & 40.00 \\
\hline Average (Rs./kg) & 12.50 & 16.33 & 15.20 & 17.50 & 8.00 & 25.00 \\
\hline \multicolumn{7}{|l|}{ Farm share on price } \\
\hline Average wholesale price (Rs./kg) & 8.00 & 25.10 & 32.73 & 16.19 & 13.36 & 31.72 \\
\hline $\begin{array}{l}\text { Average road-head price (Rs./kg in } \\
\text { Banepa market) }\end{array}$ & 6.15 & 21.95 & 27.07 & 12.90 & 9.15 & 23.93 \\
\hline $\begin{array}{l}\text { Average price share by the farmers } \\
\text { selling at Banepa (\% of the wholesale } \\
\text { price) }\end{array}$ & 77.71 & 88.21 & 83.72 & 80.64 & 69.26 & 77.56 \\
\hline
\end{tabular}

Vegetable production and marketing generally required a high cost for labor (Tables 2, 3 and 4), major part of which is supplied by household members in the farms. Even then, the farms often employed wage labors especially for transporting farm produces to road-head. Frequent uses of pesticides and other agrochemicals also accounted for considerable cost. Based on farm practices, use of the agrochemicals is crucial for high production and production risk management. However, their residues in the produces could deteriorate marketing quality rendering them impossible to reach chemically conscious markets. Compared to vegetable pockets in Kodari highway corridor, the costs due to agrochemicals and, to some extent, labor and marketing are less in Hemja. 
Since there were no special price records for Hemja supplies in Pokhara wholesale market, applying daily wholesale price records in an assessment of farm share was also not valid. Therefore, the assessment was based on farmers and traders' mentions. It was observed that farm gate prices of vegetables in Hemja were generally two to five rupees less than wholesale prices in Pokhara depending on commodity and supply situation. Vegetable farmers in Hemja, on an average, received $75 \%$ of wholesale price at farm gate. The share could vary from $48-90 \%$ (Table 6 ). Farm share on wholesale price of tomato was much higher than that of other vegetables that the farmers preferred much to cultivate, and that of cabbage, less desired by the farmers to cultivate, was lower (48-70\%). Therefore, level of income from different crops governed farmers' choices for investment and production.

Table 6: Share of farmers in Hemja on Pokhara wholesale prices

\begin{tabular}{lrrrrrr}
\hline Price description & Potato & $\begin{array}{l}\text { Cauli- } \\
\text { flower }\end{array}$ & Cabbage & Tomato & \multicolumn{1}{c}{$\begin{array}{l}\text { Cucum } \\
\text {-ber }\end{array}$} & Average \\
\hline Farm sale price & & & & & & \\
$\quad$ Minimum (Rs./kg) & 10.00 & 12.00 & 2.00 & 9.00 & 8.00 & \\
Maximum (Rs./kg) & 15.00 & 19.00 & 8.00 & 30.00 & 25.00 & \\
$\quad$ Average (Rs./kg) & 12.40 & 15.50 & 4.60 & 17.90 & 16.10 & \\
\hline Wholesale (WS) price & & & & & & \\
$\quad$ Minimum (Rs./kg) & 14.40 & 17.50 & 6.60 & 19.90 & 19.10 & \\
$\quad$ Maximum (Rs./kg) & 17.40 & 22.50 & 9.60 & 24.90 & 23.10 & \\
\hline Farm share on price & & & & & & \\
At minimum WS-price (\%) & 86 & 89 & 70 & 90 & 84 & 84 \\
At maximum WS-price (\%) & 71 & 69 & 48 & 72 & 70 & 66 \\
Average share on WS-price (\%) & 79 & 79 & 59 & 81 & 77 & 75 \\
\hline
\end{tabular}

\section{PROSPECTS OF VEGETABLE PRODUCTION AND MARKETING PROMOTION}

Some infrastructure development such as irrigation, blacktopped road and communication linking the areas to national grid of vegetable markets, electricity and diverse physiography with fertile land contributed to efficient vegetable farming. On top of which, the areas being near to major cities of the country have higher advantages of easy access to inputs, technology and other services contributing to lower cost production and marketing. Large number of farmers' groups with considerable saving of financial resources, women as well as educated youths engaged in vegetable production and marketing and some community based organizations (CBOs) committed to providing services in agriculture development are other positive aspects.

However, the vegetable farmers had complains on quality of seed and fertilizer supply, which adversely affected production and its efficiency. The farmers are much concerned on poor quality of seeds and fertilizers available in the market, and have a sense of regret on the state's inability to have control on the quality deteriorations. Potato farmers in Hemja have special concerns with non-availability of sufficient seed-tuber of locally preferred potato variety (MS-42). Owing to a deficit household supply of organic manure required in vegetable production, the farmers bought poultry manure from Chitwan while those in Araniko Highway corridor experienced soil degradation and depleting crop productivity.

Even then, the farmers have been fetching good prices for vegetable because of above described locational strengths. Moreover, growing cities in general and tourism especially in Pokhara are likely to increase demand for vegetables, thereby increasing consumption level and prices available to farmers and creating ground to expand vegetable promotion efforts. Vegetable farming can be income generating in the areas to reduce farm poverty especially in small holders. Provisions for distant supply of the produces would further increase the prices available to the farmers. The areas' potentiality to maintain regular supply of some 
vegetables such as tomato, cauliflower, cabbage and radish is a visible strength to harness market opportunities. However, some threats identified there such as increasing severity of crop diseases and pest resulting high use of pesticides, fluctuating market prices, frequent bandhas and growing quality concerns of consumers should be addressed properly while planning such development.

\section{Strengths}

1. Relatively good infrastructure including irrigation, road, electricity, nearness to market and access to services (inputs and technology)

2. Fertile land suitable for diverse production of vegetables.

3. Growing local and regional markets with improving marketing facilities.

4. Long tradition of the areas on vegetable production and marketing.

5. Empowered women and encouraged youth groups.

6. Local financial savings.

\section{Opportunities}

1. Relatively good price available to the farmers.

2. Linkages of the areas to national grids of vegetable markets.

3. Availability of land for area expansion under vegetables.

4. Growing tourism and/or nearness to major cities and trans-border market.

5. Increasing affordability of local peoples for vegetables.

\section{Weaknesses}

1. Decreasing supply of organic manure and depleting soil productivity.

2. Lack of appropriate crop varieties and quality seed supply. Poor quality seeds and fertilizers, sometimes led to complete or partial crop failure.

3. Small number of local traders and limited services from local collection centers.

4. Inaccurate weighing, provision for a kachho of almost three kilogram per $25 \mathrm{~kg}$ packet was not fair to farmers.

5. High cost of plastic house construction.

6. Low price available to relatively distant producers.

7. Price cartel, which has been easier to traders due to cellular phone, regular contact among them and perishability of vegetable products.

8. Decreased vegetable supply during late winter and early summer due to inefficiency of irrigation systems.

\section{Threats}

1. High incidence of diseases and pests requiring high use of pesticides leading to high production cost and occasional crop failure.

2. Hailstorm damage of crops and plastic houses.

3. Bird flue havoc likely to constrain manure supply.

4. Highly fluctuating market prices.

5. Frequent bandhas had direct impact on price and quality of vegetable supplies.

6. Youth's emigration in search of better opportunity.

7. Supply of cheaper vegetables from outside.

8. Increasing number of quality conscious consumers.

Fig. 4: SWOT analysis of vegetable production and marketing prospect

\section{CONCLUSION AND RECOMMENDATIONS}

Vegetable production and marketing is valued on account of its growing contribution to the national GDP and expanding areas with potentials to export earning, rural employment and poverty reduction. Such potentials of vegetable farming especially in smallholders could be harnessed only through improved performance of production and marketing systems. Some enterprising farmers have been fetching good income from year round cultivation of tomato in plastic houses and two-season cultivation of tomato, long bean, cauliflower, cabbage and cucumber in open field. Conscious of market demands for the local produces and possible price risks and added costs while selling products at market centers, the farmers strategically managed crop production in time of high demand, performed scale production of the crops saleable at farm gate and disposed them at farm gate to collectors in contact. Besides small quantity of farm produces disposed beyond road-head via farmer-collectors on commission basis, the farmers, in major, transacted the produces directly to private traders at road-head through price-negotiation. Local cooperatives and the cooperative-run 
collection-centers facilitated only in the transaction process. Because of perishability of the produces and lack of proper storage, the farmers have weaker position in price negotiation. Even then the marketing system is observed to perform well as the farms on an average were observed sharing $75 \%$ on wholesale prices, considered reasonable based on their feelings and costs involved. On such ground, vegetable farming can be good source of income to reduce farm poverty especially in small holders. Despite the facts, farm supplies are irregular and below quantity demand leaving sufficient rooms for promotion of scale production and marketing improvements. Because of harsh bargain on price and delay on payment by traders, disposing farm produces in wholesale market centers is a matter of price risks to the farmers. In addition to proper addresses of the marketing weaknesses, relevant policies and programs are essential regarding research and development on emerging pest control, suitable crop variety and seed and fertilizer quality control.

Contrasting to the costs incurred in vegetable forcing, the costs due to pesticides is high that would contribute to deterioration of product quality, environment and public health. A high residue of agro-chemical in the produces is likely to hamper their marketability especially when they are to be exported. Use of various agrochemicals such as insecticides, fungicides, hormones and growth regulators in vegetable production is also crucial to maintain high productivity and reduce production risks. On the other hand, promotion of trans-border marketing of vegetables to Tibet would increase prices available to the farmers in Kabhrepalanchok and Sindhupalchok due to proximity. 'Why vegetables produced there are hindered from transferring across the border but a big volume of Chinese products finding easy way to Kathmandu' is not much clear. Such a dilemma in vegetable-based agribusiness promotion in the country calls for appropriate and timely concerns by the policy level.

Some of the genuine problems related to production system such as diseases and pests severities, deteriorating soil environment, lack of year-round irrigation and poor quality of seed and fertilizer materials in the input market hinder vegetable farmers from realizing optimum crop productivity. Likewise, marketing related problems such as fluctuating prices due mainly to frequent bandhas in the recent context, a high weight margin for containers in market centers and poor availability of price information to farmers compared to traders contribute to market imperfectness. Both the types of problems justified areas of future efforts by the state and other agencies working there in production and marketing promotion of vegetables.

\section{REFERENCES}

AEC, FNCCI, WI and MOA, 1996. Proceedings of consultation meeting on policy constraints / facilitation for private sector involvement in specific commodity subsector. Kathmandu, Ministry of Agriculture (MOA).

Banskota, K. and Sharma, B., 1999. Traded resource flows from highland to lowland. Kathmandu, International Center for Integrated Mountain Development.

Banskota, M., 1999. Reflecting on mountain development policies in Nepal: highlights of a roundtable discussion. In: Akhtar, S and Karki, A.S. (eds.), Newsletter no-34. Kathmandu, International Center for Integrated Mountain Development.

Chapagain, D.P. and Phuyal, H., 2003. A review of agricultural policies and legal regime in Nepal. Assistance in the Review of Agricultural Policy and Legislation, TCP/NEP/0165, FAO, Rome.

DADO, 2006. Barshik Krishi Bikas Karyakram Upalabdhi (in Nepali). District Agriculture Development Office, Sindhupalchowk.

DADO, 2007a. Jilla Stariya Paket Prophayal (in Nepali). District Agriculture Development Office, Kabhrepalanchowk.

DADO, 2007b. Barsik krishi bikash karyakram tatha tathyanka ek jhalak, 2063/64. District Agriculture Development Office, Pokhara, Kaski.

Ellis, F., 1996. Agricultural Policies in Developing Countries. New York, Cambridge University Press FAO, 1998 
Hanson, J. L., 1982. A Dictionary of Economics and Commerce. London, The English Language Book Society and Mac Donald and Evans Ltd.

Koirala, G.P., Thapa, G.B. and Joshi, G.R., 1995. Can Nepalese farmers compete in the domestic market? A comparison of the relative setting and performance in agriculture of Nepal and India. Kathmandu, Winrock International.

MOA, 1998. Proceedings of the national seminar on fruit and vegetable marketing in Nepal, Kathmandu, September 15 and 16. Ministry of Agriculture, Kathmandu.

MOAC, 2004. National Agricultural Policy. Ministry of Agriculture and Cooperative, Nepal

MOAC, 2007a. Statistical Information on Nepalese Agriculture 2006/2007. Ministry of Agriculture and Cooperative, Agri-Business Promotion and Statistics Division, Nepal.

MOAC, 2007b. Selected Indicators of Nepalese Agriculture and Population. Ministry of Agriculture and Cooperative, Nepal.

MOICS, 1992. Nepal: Industrial Policy 1992. Ministry of Industry, Commerce and Supply, Nepal

NPC, 1995. Nepal agriculture perspective plan. National Planning Commission and Asian Development Bank TA No. 1854-Nep, Nepal.

NPC, 1998. The Ninth Plan. National Planning Commission, Nepal.

NPC, 2003. The Tenth Plan. National Planning Commission, Nepal.

NPC, 2007. Three Years Interim-Plan. National Planning Commission, Nepal.

Partap, T., 1999. Policy impact: the case of apple. In: S. Akhtar and A. S. Karki (eds.), Newsletter no34. International Center for Integrated Mountain Development, Kathmandu.

Pokhrel, D. M., 2005. Citrus marketing system in the mountains of Nepal: a study based on market structure, conduct and performance analyses. PhD dissertation submitted to School of Environment, Resources and Development, Asian institute of Technology, Thailand.

Pokhrel, D. M. and Thapa, G. B., 2007. Decline of mandarin grooves: a case of Syadul pocket in Nepal. Agriculture Development Journal, IV(4):61-79.

Pradhan, T., 1998. Nepal agriculture perspective plan implementation status and future action, citrus fruits-production and marketing. IAU/APP-TA, NPC, Kathmandu.

Shrestha, B. and Shrestha, R.L., 2000. Marketing of mandarin orange in the western hills of Nepal: constraints and potentials. Nepal, Lumle Agriculture Research Station.

Singh, M.K., 2008. Economics of production and marketing of vegetables in Madhya Pradesh, India. Available at: http://www.ivcs.org.uk/IJRS/Oct2005/Economics\%20article\%20\%20Manoj\%20Kumar\% 20Singh.pdf (May 15, 2008).

Thapa, G.B. and D. Paudyal, 2007. Nepal. Available at: http://www.avrdc.org/pdf/ dynamics/nepal.pdf (May 15, 2008)

Thapa, G.B., Koirala, G.P., Gill, G.J. and Thapa, M.B., 1995. Constraints on agricultural marketing in Nepal. Kathmandu, Winrock International 


\section{Annex 1a: Vegetable producers' groups/cooperatives interviewed}

Janajagriti tarkari utpadak cooperative society, 9. Kalleridanda taja tarkari/ kaphi utpadan Dhulikhel-6.

1. Kabhreli tarkari bazaar Private Limited, Banepa samuha, Sukute-9,Sindhupalchowk

2. Pragatishil Multipurpose Coop. Society, Panchkhal.

3. Budhathokidanda vegetable producers' group, Dolalghat-9.

4. Chakradevi off-season vegetable producers' group, Dhulikhel-1, Pakucha.

5. Jagaruk Krishi Klab (Shrijanshil women's multipurpose coop. soc), Shrirampati.

6. Kalika fresh vegetable producers' group, Panchkhal-6.

10. Krishi bikas samiti, Mankha-6, Khandichour.

11. Kalidevi tarkari utpadan samuha, Sangachowk1, Karkitar, Sindhupalchowk

12. Janajagaran krishak samuha, Sangachowk-7, Bahungaun, Sindhupalchowk

13. Radhakrishna krishak samuha, Sangachowk-7, Jalkini, Sindhupalchowk

14. Machhapuchchhre Famers' Group, Hemja-6, Kaski

15. Kamadhenu Famers' Group, Hemja-6, Kaski

16. Debisthan Famers' Group, Hemja-6, Kaski

17. Gourabsali Famers' Group, Hemja-6, Kaski

multipurpose coop. soc),Panchkhal-7

18. Bahudhesia Kisan Sahakari, Hemja-6, Kaski

Annex 1b: Road-head and wholesale market centers observed

1. Kabhreli tarkari bazaar, Banepa.

7. Vegetable vendors, Khandichour

2. Janajagriti tarkari utpadak sankalan kendra, Dhulikhel-6.

3. Shramik tarkari tatha phalphool sankalan kendra, Tamaghat, Panchkhal.

8. Vegetable vendors, Barhabise

9. Wholesale market center, Kalimati, Kathmandu.

10. Tukucha tarkari bazaar

4. Tarkari sankalan kendra, Tinpiple, Panchkal.

11. Banepa tarkari bazaar

12. Wholesale market center, Pokhara.

5. Tarkari sankalan kendra, Dolalghat-9

6. Vegetable vendors, Dolalghat.

13. Shri Complex Retail Market, Pokhara

\section{ACKNOWLEDGEMENT}

The author, with special thanks, acknowledges the farmers in the study area, who, despite their busy work-schedule, sincerely participated in the interviews and group discussions and patiently responded to the queries. 